\title{
Waktu Penutupan Epifisis Tulang Radius dan Ulna Bagian Distal
}

\author{
Tiara Mayang Pratiwi Lio*1, Toetik Koesbardiati ${ }^{2}$, Achmad Yudianto $^{3}$, Rosy Setiawati ${ }^{4}$ \\ ${ }^{1,2,3}$ Program Studi S2 Ilmu Forensik Sekolah Pascasarjana Universitas Airlangga, Surabaya \\ ${ }^{4}$ Departemen Radiologi RSUD Dr.Soetomo, Surabaya \\ e-mail: *11 tiaramayangpratiwilio@yahoo.com, ${ }^{2}$ toetik.koesbardiati@gmail.com, \\ 3yudi4n6sby@yahoo.co.id, ${ }^{4}$ dr_setia76@yahoo.com
}

\begin{abstract}
Abstrak
Identifikasi usia forensik bertujuan untuk menentukan dengan cara yang paling akurat usia kronologis seseorang yang tidak diketahui atau diragukan keasliannya terlibat dalam proses hokum. Salah satu metode yang digunakan adalah untuk menilai penutupan epifisis pada tulang melalui pemeriksaan radiologi. Masalah utama penggunaan metode ini berhubungan dengan relevansi dan representatif populasi referensi yang tersedia karna dipengaruhi oleh genetik dan gizi maka di perlukan data yang dapat mewakili setiap populasi. Pemeriksaan radiologi tulang pergelangan tangan dari 68 pasien laki-laki usia 1130 tahun dan 22 pasien perempuan usia 13-28 tahun di RSUD.Dr.Soetomo, Surabaya selama periode januari-april 2016 , dilakukan untuk menentukan waktu penutupan epifisis dari tulang radius dan ulna bagian distal. Penelitian ini menggunakan rancangan penelitian deskriptif cross-sectional. Kesimpulan dari penelitian ini pada laki-laki pada usia $\geq 17$ sebagian besar tulang radius dan ulna bagian distal mengalami penutupan epifisis yang telah lengkap dan pada perempuan usia $\geq 16$ sebagian besar tulang radius dan ulna bagian distal mengalami penutupan epifisis yang telah lengkap.
\end{abstract}

Kata kunci-Usia ; Penutupan epifisis ; Radius dan Ulna distal ; Laki-laki ; Perempuan

\begin{abstract}
Forensic age identification aims to determine the most accurate way a person's chronological age unknown or doubtful authenticity involved in the legal process. One method used is to assess the epiphyseal closure on the bone through radiological examinations. The main problem associated with the use of this method and the relevance of the reference population representative provided as influenced by genetics and nutrition, it needs the data to represent each population. Radiological examination of the wrist bones of 68 male patients aged 11-30 years and 22 female patients aged 13-28 years in hospital of RSUD Dr.Soetomo, Surabaya during the period of January-April 2016, carried out to determine the time of epiphyseal closure of the radius and ulna distal section. This study applied cross-sectional descriptive design. The conclusion of this study is on males at age $\geq 17$, most of the radius and ulna distal part experience a complete epiphyseal closure and on females at age $\geq 16$, most of the radius and ulna distal part experience a complete epiphyseal closure.
\end{abstract}

Keywords : Age; Epiphyseal closure; Distal radius and ulna; Male; Female 


\section{PENDAHULUAN}

Identifikasi atau pengenalan identitas seseorang pada awalnya berkembang untuk kebutuhan dalam menentukan identitas seseorang dalam proses penyidikan suatu tindak pidana khususnya penyelesaian permasalahan kriminal. Adanya perkembangan ilmu pengetahuan dan masalah sosial menjadikan identifikasi dimanfaatkan untuk keperluan yang berhubungan dengan berbagai kasus sipil baik yang melibatkan korban mati ataupun hidup seperti, kecelakaan baik di darat, laut, maupun udara, kasus terorisme, perang, bencana alam, pembunuhan, migrasi ilegal, identitas yang diragukan dan lain sebagainya (Berg dan Sabrina, 2015 ; Martin dan Cheryl, 2014 ; Anstett dan Jean-Marc, 2015 ; Bassed, 2012; Mallett et al, 2014).

Pada beberapa kasus korban mati proses identifikasi menjadi penting bukan hanya untuk menganalisis penyebab suatu kematian, namun juga upaya untuk memberikan ketenangan psikologis pada keluarga dengan adanya kepastian identitas korban pada kasus korban yang telah meninggal. Pada kasus manusia yang masih hidup juga terkadang perlu dilakukan identifikasi apabila terjadi ketidakjelasan identitas atau identitas yang diragukan dari individu tersebut. Identifikasi individu dapat dilakukan melalui beberapa parameter, yaitu identifikasi ras, usia, jenis kelamin, dan tinggi badan (Prawestiningtyas dan Agusi, 2009 ; Berg dan Sabrina, 2015).

Identifikasi usia dalam bidang forensik dibutuhkan setiap hari dalam praktek forensik saat ini dengan memperkirakan atau mengestimasi usia seseorang melalui beberapa metode. Identifikasi usia forensik bertujuan untuk menentukan dengan cara yang paling akurat usia kronologis seseorang yang tidak diketahui atau di ragukan keasliannya terlibat dalam proses hukum (Ritz-Timme et al, 2000).

Prakiraan usia dapat dilakukan pada individu hidup maupun mati. Pada individu yang telah mati atau jenazah seperti pada kasus pembunuhan, aborsi janin, ataupun bencana massal, prakiraan usia merupakan bagian dari identifikasi korban. Dalam kasus bencana massal, prakiraan usia dapat menjadikan identifikasi korban lebih sederhana dengan mengelompokkan usia korban. Selain itu pada kasus hukum pidana atau perdata identifikasi usia juga diperlukan untuk memperkirakan usia pada individu hidup, antara lain kasus pemalsuan usia ketenagakerjaan, pernikahan, atlet, perwalian anak, keimigrasian, atau pemerkosaan. Pembuktian hukum akan usia penting untuk menentukan apakah individu tersebut masih dalam kategori anak atau sudah dewasa, berkaitan dengan adanya perbedaan proses hukum atau peradilan pada anak dengan orang dewasa. Prakiraan usia juga merupakan pembuktikan yang berharga ketika akta kelahiran tidak ada atau diragukan keasliannya (Vierra, 2011 ; Eikvil et al, 2012 ; Koesbardiati, 2012 ; Burns, 2013).

Usia kronologis adalah perhitungan usia yang dimulai sejak kelahiran seseorang hingga waktu perhitungan usia. Usia biologis adalah perhitungan usia berdasarkan kematangan biologis yang dimiliki seseorang. Usia kronologis dapat diprakirakan karena bertambahnya usia seseorang seiring dengan meningkatnya tahap pertumbuhan dan perkembangan struktur tubuh berupa perubahan fisik atau yang dikenal sebagai usia biologis, yang konstan sehingga setiap tahap dari proses perubahan tersebut dapat dihubungkan dengan usia seorang individu (Iscan dan Maryna, 2013 ; Tersigni-Tarrant dan Natalie, 2013).

Tubuh manusia tumbuh dan menjadi matang dengan bertambahnya usia, terutama pada anak-anak dan remaja. Oleh karena itu, gagasan utama dibalik metode medis adalah untuk membandingkan pengukuran kedewasaan fisik tubuh dengan bertambahnya usia. Namun, karena masingmasing variasi dalam penentuan baik rangka maupun perkembangan gigi, hasil dari setiap metode memiliki ketidakpastian apabila diaplikasikan kepada satu individu. Ada juga masalah yang berhubungan dengan relevansi dan representatif populasi referensi yang tersedia dimana usia biologis dipengaruhi oleh genetik dan gizi sehingga akan selalu ada variasi biologis dan ketidakpastian dikaitkan dengan perkiraan usia ( TersigniTarrant dan Natalie, 2013 ; Berg dan Sabrina, 2015).

Di beberapa negara saat ini belum ada 
kepastian tentang metode mana yang digunakan untuk identifikasi usia. Mayoritas negara menilai usia berdasarkan pemeriksaan medis dari tulang dan/atau perkembangan gigi, penampilan fisik dan wawancara, sedangkan beberapa negara bergantung pada non penilaian medis saja. Berbagai negara juga menggunakan berbagai margin presisi untuk setiap metode dan pendekatan yang berbeda untuk menggabungkan hasil ketika beberapa metode digunakan (Eikvil et al, 2012).

Identifikasi usia melalui rangka tubuh dapat diketahui berdasarkan jumlah tulang yang telah muncul, bersatunya epiphysis dengan diaphysis (penutupan epifisis) pada tulang panjang, perubahan morfologi pada symphysis pubis, drajat penutupan sutura maupun drajat kalsifikasi dan erupsi gigi yang dilakukan baik dengan menggunakan pemeriksaan makroskopik, mikroskopik maupun radiograf (Lovejoy et al, 1985; Ubelaker, 1989; Brook and Suchey, 1990; Buikstra dan Ubelaker, 1994; dalam Indriati, 2010).

Terdapat beberapa cara penentuan usia biologis berdasarkan penutupan epiphysis dengan menggunakan radiograf seperti tabel standart Greulich dan Pyle tahun 1959, tabel standar Girdany dan Golden tahun 1952 dan metode Tanner Whitehouse 1962. Penentuan usia biologis dengan tabel standard Greulich dan Pyle, radiograf pasien dibandingkan dengan standard radiograf Greulich dan Pyle dengan jenis kelamin yang sama dan dipilih yang paling mendekati dengan gambaran radiograf pasien. Penentuan usia biologis dengan tabel standar Girdany dan Golden dilakukan berdasarkan pengamatan pada titik-titik osifikasi tulang dimana osifikasi pada suatu tulang akan menunjukkan rentan usia tertentu. Penentuan usia berdasarkan metode Tanner Whitehouse (TW )dilakukan dengan membagi daerah tangan menjadi 20 regio atau Regions of Interest (ROIs). Tiap lokasi ROI kemudian ditentukan berada pada stage keberapa berdasarkan pembagian oleh TW dan perkiraan usia dilakukan dengan menjumlahkan stage tiap ROI kemudian disesuaikan dengan tabel Tanner Whitehouse. (Gilsanz dan Osman, 2012 ; Girdany dan Golden, 1952 dalam Thali et al, 2011 ; Bakthula dan Suneeta, 2014).

Identifikasi usia berdasarkan penutupan epiphysis dapat dilakukan berdasarkan penilaian epiphysis dari tulang-tulang yang berada di daerah tangan sebab berdasarkan hasil penelitian sebelumnnya dirasa merupakan yang paling akurat dan paling gampang untuk dilakukan. Penutupan epiphysis di daerah tangan diperkirakan dimulai sejak individu berusia 11 tahun dan menutup seutuhnya pada usia 28-30 tahun (Schmeling et al, 2011 ; Vierra, 2011 ; Black et al, 2010) .

Identifikasi usia berdasarkan rangka tubuh umumnnya dilakukan dengan menggunakan tulang yang telah bersih dari jaringan lunak, hal ini jelas akan memakan waktu dalam proses identifikasi jika korban ditemukan dalam keadaan komponen skeletal masih sebagian atau seluruhnya dilapisi jaringan lunak atau pada manusia yang masih dalam keadaan hidup sehingga evaluasi radiologi dari parameter antropologi akan sangat membantu proses identifikasi dalam keadaan seperti ini, dimana kita dapat melihat bagian dalam tubuh pada manusia yang masih memiliki jaringan lunak atau masih hidup sekalipun (Stimson dan Curtis, 1997; Nobelprize.org, 2008 dan Röntgen, 1967 dalam Mallett et al, 2014).

Alat radiografi yang biasa digunakan ialah X-ray atau konvensional radiografi, Computed Tomography scan (CT scan), Magnetic Resonance Imaging atau MRI maupun Untrasonographi atau USG. Masing masing media memiliki keuntungan dan kekurangannya masingmasing.

Masalah yang paling sering muncul dalam penggunaan media radiografi adalah efek radiasi yang ditimbulkan, gambar yang dihasilkan oleh media tersebut, dan ketersediaan alat. Berdasarkan hal tersebut penggunaan radiologi konvensional atau X-ray yang paling disarankan penggunaannya (Ramsthaler et al, 2009 ; Serin et al, 2016 ; Ekizoglu et al, 2015 a,b,c $_{\text {c }}$.

Berdasarkan kebutuhan akan identifikasi usia forensik, metode yang ada, ketersediaan alat radiologi yang umumnnya dimiliki di seluruh daerah di Indonesia yaitu foto rontgen atau $\mathrm{x}$-ray, dan adannya masalah yang berhubungan dengan relevansi dan representatif populasi referensi yang 
tersedia dimana usia biologis dipengaruhi oleh genetik dan gizi maka dirasa perlu dilakukan penelitian waktu penutupan epifisis berdasarkan gambaran foto rontgen tulang radius dan ulna pada pasien laki-laki RSUD.Dr.Soetomo Surabaya. Diharapkan penelitian ini dapat diterapkan sebagai referensi dalam penelitian-penelitian selanjutnnya dan identifikasi usia forensik.

\section{BAHAN PENELITIAN}

Bahan Penelitian ini dalah data sekunder berupa hasil foto rontgen tulang pergelangan tangan dari rekam medis pasien RSUD.Dr.Soetomo, Surabaya pada bulan januari-april 2016 dengan kriteria jenis kelamin laki-laki dan perempuan, usia 11-30 tahun, pasien tidak memiliki penyakit gangguan pada tumbuh kembang tulangnya dan hasil foto memenuhi standar foto rontgen yang baik. Pengambilan sampel berdasarkan izin dari kepala instalasi radiologi dan lulus ethical clearance RSUD.Dr.Soetomo, Surabaya.

\subsection{Populasi Sampel dan Besar Sampel}

Populasi pada penelitian ini adalah hasil foto rontgen tulang radius dan ulna bagian distal pasien laki-laki dan perempuan usia 11-30 tahun di RSUD. Dr.Soetomo, Surabaya selama bulan Januari-April 2016. Semua populasi yang memenuhi kriteria akan digunakan sebagai sampel sehingga tidak digunakan rumus besar sampel dalam penelitian ini.

\section{METODE PENELITIAN}

Penelitian waktu penutupan epifisis pada pasien di RSUD Dr.Soetomo, Surabaya menggunakan jenis penelitian observasional dimana peneliti melakukan pengamatan pada sampel tanpa melakukan perlakuan apapun.

Penelitian ini merupakan penelitian deskriptif cross-sectional untuk menggambarkan atau mendeskripsikan suatu hasil penelitian yang menggunakan rancangan atau desain observasi yang semua pengukuran variabel yang diteliti dilakukan pada satu waktu. Hal ini dilakukan dengan menilai tingkat penutupan epifisis pada tulang radius dan ulna bagian distal pada sampel penelitian.

Setelah dilakukan maping data sekunder yaitu foto rontgen pergelangan tangan pasien selama bulan januari-april 2016 kemudian dilakukan seleksi sampel sesuai dengan kriteria yang dibutuhkan yakni :

- Foto rontgen tulang radius dan ulna bagian distal

- Foto rontgen pasien usia 11-30 tshun

- Foto rontgen pasien dengan jenis kelamin laki-laki dan perempuan

- Hasil foto rontgen memenuhi standar foto yang baik

Foto rontgen yang memenuhi kriteria kemudian akan dibaca oleh spesialis radiologi dan dinilai sesuai tingkat penutupan epifisis

\subsection{Variabel Penelitian dan Definisi Operasional}

Usia kronologis adalah perhitungan usia yang dimulai dari saat kelahiran seseorang sampai waktu perhitungan usia (Iscan dan Steyn, 2013). Cara mengukurnya dengan melihat data atau keterangan pada rekam medis pasien. Data yang diperoleh berupa usia pasien dalam tahun.

Waktu penutupan epifisis adalah adalah saat bersatunya epiphysis dengan diaphysis (Iscan dan Steyn, 2013). Cara mengukurnnya dengan melihat gambaran penutupan epifisis pada foto rontgen. Data yang diperoleh berupa keterangan drajat atau tingkatan penutupan epifisis.

\subsection{Tingkat Penutupan Epifisis}

Penutupan epifisis merupakan salah satu metode yang sering digunakan dalam menentukan usia kronologi seseorang. Dimana penutupan epifisis itu sendiri merupakan tingkatan kematangan dari pertumbuhan tulang yang menggambarkan usia biologis seseorang. Ada beberapa klasifikasi dalam menentukan tingkat penutupan epifisis, salah satunnya dengan membagi membagi menjadi 4 kategori yaitu 0,1,2, dan 3 (Sahni et al, 1994). Penutupan epifisis diklasifikasikan sebagai :

$0 \quad$ :Jika belum ada penutupan sama sekali

1 :Jika telah ada penutupan epifisis yang kurang dari setengah bagian area epifisis

2 :Jika telah ada penutupan epifisis setengah bagian dari area epifisis 
Jurnal Biosains Pascasarjana Vol. 19 (2017) pp

(C) (2017) Sekolah Pascasarjana Universitas Airlangga, Indonesia

3 :Jika penutupan epifisis telah lengkap seluruhnnya
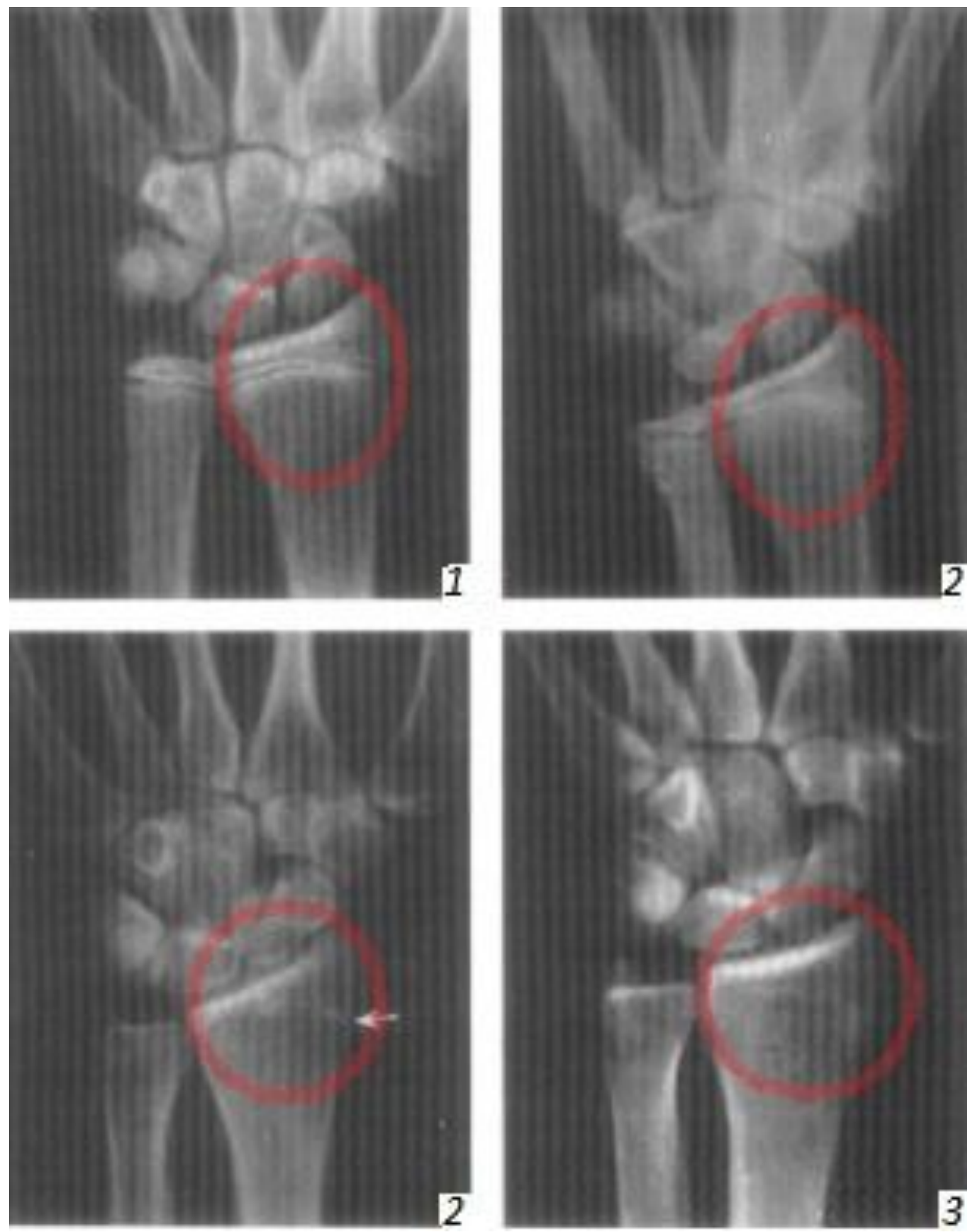

Gambar 1. Tingkat penutupan epifisis tulang (Sahni et al, 1994) 


\section{HASIL DAN PEMBAHASAN}

Hasil penelitian tingkat penutupan epifisis pada tulang radius dan ulna bagian distal pada pasien laki-laki di RSUD.Dr.Soetomo, Surabaya di tunjukkan pada Tabel 1 dan hasil penelitian tingkat penutupan epifisis pada tulang radius dan ulna bagian distal pada pasien perempuan di RSUD.Dr.Soetomo, Surabaya di tunjukkan pada Tabel 2.

Tabel 1. Hasil Penelitian Waktu Penutupan Epifisis Tulang Radius dan Ulna Bagian Distal pada Laki-laki usia 11-30 tahun di RSUD Dr.Soetomo, Surabaya selama Januari-April 2016

\begin{tabular}{|c|c|c|c|c|c|c|c|c|c|c|}
\hline \multirow{2}{*}{ No. } & \multirow{2}{*}{$\begin{array}{c}\text { Usia } \\
\text { Kronologis } \\
\text { (tahun) }\end{array}$} & \multirow{2}{*}{$\begin{array}{l}\text { Jumlah } \\
\text { Sampel }\end{array}$} & \multicolumn{4}{|c|}{ Radius bagian Distal } & \multicolumn{4}{|c|}{ Ulna bagian Distal } \\
\hline & & & 0 & 1 & 2 & 3 & 0 & 1 & 2 & 3 \\
\hline 1. & 11 & & & & 2 & & & & 2 & \\
\hline 2. & 12 & & & 1 & 2 & & & & 3 & \\
\hline 3. & 13 & & & & 1 & & & & 1 & \\
\hline 4. & 14 & & & & 5 & & & & 5 & \\
\hline 5. & 15 & & & & & & & & & \\
\hline 6. & 16 & & & & 5 & & & & 4 & 1 \\
\hline 7. & 17 & & & & 3 & 2 & & & 1 & 4 \\
\hline 8. & 18 & & & & & 1 & & & & 1 \\
\hline 9. & 19 & & & & 1 & 1 & & & & 2 \\
\hline 10. & 20 & & & & & 2 & & & & 2 \\
\hline 11. & 21 & & & & & 2 & & & & 2 \\
\hline 12. & 22 & & & & & 6 & & & & 6 \\
\hline 13. & 23 & & & & & 5 & & & & 5 \\
\hline 14. & 24 & & & & & 5 & & & & 5 \\
\hline 15. & 25 & & & & & 2 & & & & 2 \\
\hline 16. & 26 & & & & & 6 & & & & 6 \\
\hline 17. & 27 & & & & 1 & 5 & & & & 6 \\
\hline 18. & 28 & & & & & 5 & & & & 5 \\
\hline 19. & 29 & & & & & 2 & & & & 2 \\
\hline
\end{tabular}


Jurnal Biosains Pascasarjana Vol. 19 (2017) pp

(C) (2017) Sekolah Pascasarjana Universitas Airlangga, Indonesia

\begin{tabular}{|r|r|r|r|r|r|r|r|r|r|r|}
\hline 20. & 30 & & & & & 3 & & & & 3 \\
\hline \multicolumn{2}{|r|}{ Total } & 68 & & 1 & 20 & 47 & & & 16 & 52 \\
\hline
\end{tabular}

Tabel 2. Hasil Penelitian Waktu Penutupan Epifisis Tulang Radius dan Ulna bagian Distal pada Perempuan Usia 11-30 tahun di RSUD Dr.Soetomo,Surabaya selama Januari-April 2016

\begin{tabular}{|c|c|c|c|c|c|c|c|c|c|c|}
\hline \multirow{2}{*}{ No. } & \multirow{2}{*}{$\begin{array}{c}\text { Usia } \\
\text { Kronologis } \\
\text { (tahun) }\end{array}$} & \multirow{2}{*}{$\begin{array}{l}\text { Jumlah } \\
\text { Sampel }\end{array}$} & \multicolumn{4}{|c|}{ Radius bagian Distal } & \multicolumn{4}{|c|}{ Ulna bagian Distal } \\
\hline & & & $\mathbf{0}$ & 1 & 2 & 3 & 0 & 1 & 2 & 3 \\
\hline 21. & 11 & & & & & & & & & \\
\hline 22. & 12 & & & & & & & & & \\
\hline 23. & 13 & 1 & & & 1 & & & & 1 & \\
\hline 24. & 14 & & & & & & & & & \\
\hline 25. & 15 & & & & & & & & & \\
\hline 26. & 16 & 5 & & & 4 & 1 & & & 4 & 1 \\
\hline 27. & 17 & 3 & & & 1 & 2 & & & 1 & 2 \\
\hline 28. & 18 & 1 & & & & 1 & & & & 1 \\
\hline 29. & 19 & 3 & & & 2 & 1 & & & & 3 \\
\hline 30. & 20 & 2 & & & 1 & 1 & & & & 2 \\
\hline 31. & 21 & 1 & & & 1 & & & & & 1 \\
\hline 32. & 22 & & & & & & & & & \\
\hline 33. & 23 & 1 & & & & & & & & 1 \\
\hline 34. & 24 & 2 & & & & 2 & & & & 2 \\
\hline 35. & 25 & 1 & & & & 1 & & & & 1 \\
\hline 36. & 26 & & & & & & & & & \\
\hline 37. & 27 & & & & & & & & & \\
\hline 38. & 28 & 2 & & & & 2 & & & & 2 \\
\hline 39. & 29 & & & & & & & & & \\
\hline 40. & 30 & & & & & & & & & \\
\hline & Total & 22 & & & 10 & 12 & & & 6 & 16 \\
\hline
\end{tabular}




\subsection{Hasil Penelitian Penutupan Epifisis Tulang Radius Bagian Distal pada Laki-laki}

Berdasarkan hasil penelitian foto rontgen radius bagian distal laki-laki yaitu usia 11-30 tahun. Usia 11 tahun, 2 sampel menunjukkan epifisis tulang telah menutup dengan luas area penutupan lebih dari setengah bagian area epifisis ; usia 12 tahun, 1 sampel menunjukkan epifisis tulang telah menutup dengan luas area penutupan kurang dari setengah bagian area epifisis dan 2 sampel menunjukkan epifisis tulang telah menutup dengan luas area penutupan lebih dari setengah bagian area epifisis ; usia 13 tahun, 1 sampel menunjukkan epifisis tulang radius bagian distal telah menutup dengan luas area penutupan lebih dari setengah bagian area epifisis ; usia 14 tahun, 5 sampel menunjukkan epifisis tulang radius bagian distal telah menutup dengan luas area penutupan lebih dari setengah bagian area epifisis ; usia 16 tahun, 5 sampel menunjukkan epifisis tulang radius bagian distal telah menutup dengan luas area penutupan lebih dari setengah bagian area ; usia 17 tahun, 3 sampel menunjukkan epifisis tulang radius bagian distal telah menutup dengan luas area penutupan lebih dari setengah bagian area epifisis, 2 sampel menunjukkan epifisis tulang radius bagian distal telah menutup seluruhnnya pada area epifisis ; usia 18 tahun 1 sampel menunjukkan epifisis tulang radius bagian distal telah menutup seluruhnnya pada area epifisis ; usia 19 tahun, 1 sampel menunjukkan epifisis tulang radius bagian distal telah menutup dengan luas area penutupan lebih dari setengah bagian area epifisis, 1 sampel menunjukkan epifisis tulang radius bagian distal telah menutup seluruhnnya pada area epifisis ; usia 20 tahun, 2 sampel menunjukkan epifisis tulang radius bagian distal telah menutup seluruhnnya pada area epifisis ; usia 21 tahun , 2 sampel menunjukkan epifisis tulang radius bagian distal telah menutup seluruhnnya pada area epifisis ; usia 22 tahun, 6 sampel menunjukkan epifisis tulang radius bagian distal telah menutup seluruhnnya pada area epifisis ; usia 23 tahun, 5 sampel menunjukkan epifisis tulang radius bagian distal telah menutup seluruhnnya pada area epifisis ; usia 24 tahun, 5 sampel menunjukkan epifisis tulang radius bagian distal telah menutup seluruhnnya pada area epifisis ; usia 25 tahun, 2 sampel menunjukkan epifisis tulang radius bagian distal telah menutup seluruhnnya pada area epifisis ; usia 26 tahun, 6 sampel menunjukkan epifisis tulang radius bagian distal telah menutup seluruhnnya pada area epifisis ; usia 27 tahun, 1 sampel menunjukkan epifisis tulang radius bagian distal telah menutup dengan luas area penutupan lebih dari setengah bagian area epifisis dan 5 sampel menunjukkan epifisis tulang radius bagian distal telah menutup seluruhnnya pada area epifisis ; usia 28 tahun, 5 sampel menunjukkan epifisis tulang radius bagian distal telah menutup seluruhnnya pada area epifisis ; usia 29 tahun, 2 sampel menunjukkan epifisis tulang radius bagian distal telah menutup seluruhnnya pada area epifisis; usia 30 tahun, 3 sampel menunjukkan epifisis tulang radius bagian diatal telah menutup seluruhnnya pada area epifisis.

\subsection{Hasil Penelitian Penutupan Epifisis Tulang Ulna Bagian Distal pada Laki-laki}

Berdasarkan hasil penelitian foto rontgen ulna bagian distal laki-laki yaitu usia 11 tahun, 2 sampel menunjukkan epifisis tulang ulna bagian distal telah menutup dengan luas area penutupan lebih dari setengah bagian area epifisis; usia 12 tahun, 3 sampel menunjukkan epifisis tulang ulna bagian distal telah menutup dengan luas area penutupan lebih dari setengah bagian area epifisis ; usia 13 tahun, 1 sampel menunjukkan epifisis tulang ulna bagian distal telah menutup dengan luas area penutupan lebih dari setengah bagian area epifisis ; usia 14 tahun, 5 sampel menunjukkan epifisis tulang ulna bagian distal telah menutup dengan luas area penutupan lebih dari setengah bagian area epifisis ; usia 16 tahun, 4 sampel 
menunjukkan epifisis tulang ulna bagian distal telah menutup dengan luas area penutupan lebih dari setengah bagian area dan 1 sampel menunjukkan epifisis tulang ulna bagian distal telah menutup seluruhnnya pada area epifisis ; usia 17 tahun, 1 sampel menunjukkan epifisis tulang ulna bagian distal telah menutup dengan luas area penutupan lebih dari setengah bagian area epifisis, 4 sampel menunjukkan epifisis tulang ulna bagian distal telah menutup seluruhnnya pada area epifisis ; usia 18 tahun 1 sampel menunjukkan epifisis tulang ulna bagian distal telah menutup seluruhnnya pada area epifisis ; usia 19 tahun, 2 sampel menunjukkan epifisis tulang ulna bagian distal telah menutup seluruhnnya pada area epifisis ; usia 20 tahun , 2 sampel menunjukkan epifisis tulang ulna bagian distal telah menutup seluruhnnya pada area epifisis ; usia 21 tahun , 2 sampel menunjukkan epifisis tulang ulna bagian distal telah menutup seluruhnnya pada area epifisis ; usia 22 tahun, 6 sampel menunjukkan epifisis tulang ulna bagian distal telah menutup seluruhnnya pada area epifisis ; usia 23 tahun, 5 sampel menunjukkan epifisis tulang ulna bagian distal telah menutup seluruhnnya pada area epifisis ; usia 24 tahun, 5 sampel menunjukkan epifisis tulang ulna bagian distal telah menutup seluruhnnya pada area epifisis ; usia 25 tahun, 2 sampel menunjukkan epifisis tulang ulna bagian distal telah menutup seluruhnnya pada area epifisis ; usia 26 tahun, 6 sampel menunjukkan epifisis tulang ulna bagian distal telah menutup seluruhnnya pada area epifisis ; usia 27 tahun, 6 sampel menunjukkan epifisis tulang ulna bagian distal telah menutup seluruhnnya pada area epifisis ; usia 28 tahun, 5 sampel menunjukkan epifisis tulang ulna bagian distal telah menutup seluruhnnya pada area epifisis ; usia 29 tahun, 2 sampel menunjukkan epifisis tulang ulna bagian distal telah menutup seluruhnnya pada area epifisis; usia 30 tahun, 3 sampel menunjukkan epifisis tulang ulna bagian diatal telah menutup seluruhnnya pada area epifisis.

\subsection{Hasil Penelitian Penutupan Epifisis Tulang Radius Bagian Distal pada Perempuan}

Berdasarkan hasil penelitian foto rontgen radius bagian distal perempuan yaitu usia 13-28 tahun. Usia 13 tahun, 1 sampel menunjukkan epifisis tulang telah menutup dengan luas area penutupan lebih dari setengah bagian area epifisis ; usia 16 tahun, 4 sampel menunjukkan epifisis tulang telah menutup dengan luas area penutupan lebih dari setengah bagian area epifisis dan 1 sampel menunjukkan epifisis tulang radius bagian distal telah menutup seluruhnnya pada area epifisis ; usia 17 tahun, 1 sampel menunjukkan epifisis tulang radius bagian distal telah menutup dengan luas area penutupan lebih dari setengah bagian area epifisis dan 2 sampel menunjukkan epifisis tulang radius bagian distal telah menutup seluruhnnya pada area epifisis ; usia 18 tahun, 1 sampel menunjukkan epifisis tulang radius bagian distal telah menutup seluruhnnya pada area epifisis ; usia 19 tahun, 2 sampel menunjukkan epifisis tulang radius bagian distal telah menutup dengan luas area penutupan lebih dari setengah bagian area dan 1 sampel menunjukkan epifisis tulang radius bagian distal telah menutup seluruhnnya pada area epifisis ; usia 20 tahun, 1 sampel menunjukkan epifisis tulang radius bagian distal telah menutup dengan luas area penutupan lebih dari setengah bagian area epifisis dan 1 sampel menunjukkan epifisis tulang radius bagian distal telah menutup seluruhnnya pada area epifisis ; usia 21 tahun 1 sampel menunjukkan epifisis tulang radius bagian distal telah menutup dengan luas area penutupan lebih dari setengah bagian area epifisis ; usia 24 tahun , 2 sampel menunjukkan epifisis tulang radius bagian distal telah menutup seluruhnnya pada area epifisis ; usia 25 tahun , 1 sampel menunjukkan epifisis tulang radius bagian distal telah menutup seluruhnnya pada area epifisis ; usia 28 tahun, 2 sampel menunjukkan epifisis tulang radius bagian distal telah menutup seluruhnnya pada area epifisis.

\subsection{Hasil Penelitian Penutupan Epifisis Tulang Radius Bagian Distal pada Perempuan}

Berdasarkan hasil penelitian foto rontgen ulna bagian distal perempuan yaitu 
usia 13-28 tahun. Usia 13 tahun, 1 sampel menunjukkan epifisis tulang telah menutup dengan luas area penutupan lebih dari setengah bagian area epifisis ; usia 16 tahun, 4 sampel menunjukkan epifisis tulang telah menutup dengan luas area penutupan lebih dari setengah bagian area epifisis dan 1 sampel menunjukkan epifisis tulang ulna bagian distal telah menutup seluruhnnya pada area epifisis ; usia 17 tahun, 1 sampel menunjukkan epifisis tulang ulna bagian distal telah menutup dengan luas area penutupan lebih dari setengah bagian area epifisis dan 2 sampel menunjukkan epifisis tulang ulna bagian distal telah menutup seluruhnnya pada area epifisis ; usia 18 tahun, 1 sampel menunjukkan epifisis tulang ulna bagian distal telah menutup seluruhnnya pada area epifisis ; usia 19 tahun, 3 sampel menunjukkan epifisis tulang ulna bagian distal telah menutup seluruhnnya pada area epifisis ; usia 20 tahun, 2 sampel menunjukkan epifisis tulang ulna bagian distal telah menutup seluruhnnya pada area epifisis ; usia 21 tahun, 1 sampel menunjukkan epifisis tulang ulna bagian distal telah menutup seluruhnnya pada area epifisis ; usia 23 tahun, 1 sampel menunjukkan epifisis tulang ulna bagian distal telah menutup seluruhnnya pada area epifisis ; usia 24 tahun, 2 sampel menunjukkan epifisis tulang ulna bagian distal telah menutup seluruhnnya pada area epifisis ; usia 25 tahun, 1 sampel menunjukkan epifisis tulang ulna bagian distal telah menutup seluruhnnya pada area epifisis ; usia 28 tahun, 2 sampel menunjukkan epifisis tulang ulna bagian distal telah menutup seluruhnnya pada area epifisis.

\subsection{Penelitian Radius dan Ulna Pembahasan Hasil bagian Distal pada Laki-laki}

\begin{tabular}{|r|c|c|c|c|c|}
\hline \multirow{2}{*}{ No. } & & \multicolumn{4}{|c|}{ Penutupan Epifisis Laki-Laki Usia 11-30 Tahun } \\
\cline { 3 - 6 } & & $\mathbf{0}$ & $\mathbf{1}$ & $\mathbf{2}$ & $\mathbf{3}$ \\
\hline 1. & Radius bagian Distal & - & $\leq 12$ & $11-19$ & $\geq 17$ \\
\hline 2. & Ulna bagian Distal & - & - & $11-17$ & $\geq 16$ \\
\hline
\end{tabular}

Tabel 3. Analisis Hasil Penelitian Penutupan Epifisis pada Laki-Laki

Jumlah sampel dalam dalam penelitian ini yaitu 68 foto rontgen radius bagian distal, jenis kelamin laki-laki dengan rentan usia
11-30 tahun. Berdasarkan data diketahui 1 sampel usia 12 tahun menunjukkan penutupan epifisis radius distal kurang dari setengah bagian epifisis, 20 sampel dimana 19 sampel usia 11-17 tahun dan 1 sampel usia 19 tahun menunjukkan penutupan epifisis radius distal lebih dari setengah bagian epifisis, dan 47 sampel usia 17-30 tahun menunjukkan penutupan epifisis radius bagian distal teleh sempurna atau telah menutup sepenuhnya.

Jumlah sampel dalam dalam penelitian ini yaitu 68 foto rontgen ulna bagian distal, jenis kelamin laki-laki dengan rentan usia 11-30 tahun. Berdasarkan data diketahui 16 sampel pada usia 11-17 tahun menunjukkan penutupan epifisis ulna distal lebih dari setengah bagian epifisis, dan 52 sampel pada usia 16-30 tahun menunjukkan penutupan epifisis ulna bagian distal teleh sempurna atau telah menutup sepenuhnya.

\subsection{Pembahasan Hasil Radius dan Ulna bagian Distal pada Perempuan}

\begin{tabular}{|r|l|l|l|l|l|}
\hline \multirow{2}{*}{ No. } & & \multicolumn{4}{|c|}{ Penutupan Epifisis Perempuan Usia 11-30 Tahun } \\
\cline { 3 - 6 } & & $\mathbf{0}$ & $\mathbf{1}$ & $\mathbf{2}$ & $\mathbf{3}$ \\
\hline 1. & Radius bagian Distal & - & - & $13-21$ & $\geq 16$ \\
\hline 2. & Uina bagian Distal & - & - & $13-17$ & $\geq 16$ \\
\hline
\end{tabular}

Tabel 4. Analisis Hasil Penelitian Penutupan Epifisis pada Perempuan

Jumlah sampel dalam dalam penelitian ini yaitu 22 foto rontgen radius bagian distal, jenis kelamin perempuan dengan rentan usia 13-28 tahun. Berdasarkan data diketahui 10 sampel usia 13-21 tahun menunjukkan penutupan epifisis radius distal kurang dari setengah bagian epifisis, 12 sampel usia 1628 tahun menunjukkan penutupan epifisis radius bagian distal teleh sempurna atau telah menutup sepenuhnya.

Jumlah sampel dalam dalam penelitian ini yaitu 22 foto rontgen ulna bagian distal, jenis kelamin perempuan dengan rentan usia 13-28 tahun. Berdasarkan data diketahui 6 sampel usia 13-17 tahun menunjukkan penutupan epifisis ulna distal kurang dari setengah bagian epifisis, 16 sampel usia 1628 tahun menunjukkan penutupan epifisis ulna bagian distal teleh sempurna atau telah menutup sepenuhnya.

\section{KESIMPULAN DAN SARAN}


Adapun kesimpulan dari penelitian ini yakni pada laki-laki usia 11-19 tahun tulang radius bagian distal sebagian besar mengalami penutupan epifisis dengan luas lebih dari setengah bagian epifisis tersebut, pada usia 11-17 tahun tulang ulna bagian distal sebagian besar mengalami penutupan epifisis dengan luas lebih dari setengah bagian epifisis tersebut, dan pada usia $\geq 17$ sebagian besar tulang radius dan ulna bagian distal mengalami penutupan epifisis yang telah lengkap. Pada Perempuan usia 13-21 tahun tulang radius bagian distal sebagian besar mengalami penutupan epifisis dengan luas lebih dari setengah bagian epifisis tersebut, pada usia 13-17 tahun tulang ulna bagian distal sebgaian besar mengalami penutupan epifisis dengan luas lebih dari setengah bagian epifisis tersebut, dan pada usia $\geq 16$ sebagian besar tulang radius dan ulna bagian distal mengalami penutupan epifisis yang telah lengkap

Saran untuk penelitian selanjutnnya agar melakukan penelitian pada usia kurang dari 11 tahun untuk menilai tinggat penutupan epifisis.

\section{UCAPAN TERIMA KASIH}

Terimakasih kepada Ibu Toetik Koesbardiati dan dr.Achmad Yudianto atas segala arahan, masukan dan saran bagi penelitian ini, kepada dr.Rosy Setiawan Sp.Rad yang telah membantu menilai tingkat penutupan epifisis dari foto rontgen, dan Kepada ibu Era, staf departemen radiologi RSUD.Dr.Soetomo, Surabaya yang telah membantu pengumpulan sampel pada penelitian ini.

\section{DAFTAR PUSTAKA}

Anstett, E. dan Jean-Marc,D. 2015. Human remains and Identification Mass Violence, Genocide, and The Forensic Turn. Manchester University Press : Manchester . hal.1-19

Bakthula, R. dan Suneeta, A. 2014. Automated Human Bone Age Assessment using Image Processing Methods - Survey. International Journal of Computer Applications Volume 104 - No.13

Bassed, R.B. 2012. Advances in Forensic Age Estimation. Forensic Science Medicine and Pathology 8:194-196
Berg, G.E. dan Sabrina,C.T. 2015. Biological Affinity in Forensic Identification of Human Skeletal Remains: Beyond Black and White. CRC Press: Boca Raton.

Black, S., Anil, A. dan Jason, P. 2010. Age Estimation in The Living: The Practitioners Guide. John Wiley \& Sons Ltd. UK. hal.1-291

Burns, K.R. 2013. Forensic Anthropology Training Manual Third Edition. Pearson Education, Inc : USA. hal.3221

Eikvil, Line., Sigrid,I.K., Andre,T., Marion,H. dan Jens, G. 2012. Age Estimation in Youths and Young Adults: A Summery of The Needs for Methodological Research and Development. Norsk Regnesentral : Norway. hal.7-26

Ekizoglu, O., Elif,H., Ercan,I., Ibrahim,S., Dilek,S. dan Mustafa,G.B. dan Ismail,O.C. 2015b. Forensic Age Estimation by The Schmeling Method: Computed Tomography Analysis of The Medial Clavicular Epiphysis. International Journal of Legal Medicine 129:203-210

Ekizoglu, O., Elif,H., Ismail,O.C., Ercan,I., Sema,A. dan Mustafa,G.B. 2015c. Magnetic Resonance Imaging of Distal Tibia and Calcaneus for Forensic Age Estimation in Living Individuals. International Journal of Legal Medicine 129:825-831

Ekizoglu, O., Ercan,I., Irem,E., Elif,H., Mustafa,G.B., Cemal,K., Ali,R. dan Ismail,O.C. 2015a. Computed Tomography Evaluation of The Iliac Crest Apophysis: Age Estimation in Living Individuals. International Journal of Legal Medicine

Gilsanz, V. dan Osman,R. 2012. Hand Bone Age: A Digital Atlas of Skeletal Maturity Second Edition. SpringerVerlag : Berlin. hal.3-9

Girdany, B. R. dan Golden,R. 1952. Centers of Ossifiation of The Skeleton. Am. J. Roentgenol 68,922

Indriati, E. 2010. Antropologi Forensik: Identifikasi Rangka Manusia, Aplikasi Antropologi Biologis dalam Konteks Hukum. 
Yogyakarta: Gajah Mada

University Press;. p. 59-78.

Iscan, M.Y., Maryna,S. 2013. The Human

Skeleton in Forensic Medicine Third

Edition. Charles C Thomas : USA

Koesbardiati, T. 2012. Buku Ajar

Antropologiforensik. PT.Revka

Petra Media; Surabaya. p. 91-110

Mallett, X., Teri,B. dan Rachel,B. 2014. Advance in Forensic Human Identificatin. CRC Press : Boca Raton. hal.ix-273

Mallett, X., Teri,B. dan Rachel,B. 2014. Advance in Forensic Human Identificatin. CRC Press : Boca Raton. hal.ix-273

Martin, D.L. dan Cheryl,P.A. 2014. Bioarchaeological and Forensic Perspectives on Violence : How Violent Death is Interpreted from Skeletal Remains. Cambridge University Press : UK. hal.3-14

Prawestiningtyas, E. dan Agus,M.A. 2009. Forensic Identification Based on Both Primary and Secondary Examination Priority in Victim Identifiers on Two Different Mass Disaster Cases (Identifikasi Forensik Berdasarkan Pemeriksaan Primer dan Sekunder Sebagai Penentu Identitas Korban pada Dua Kasus Bencana Massal). Jurnal Kedokteran Brawijaya, Vol XXV, No. 2

Ramsthaler, F., P,Proschek., W,Betz. dan M,A.Verhoff. 2009. How Reliable are The Risk Estimates for X-Ray Examinations in Forensic Age Estimations? A Safety Update. International Journal of Legal Medicine 123:199-204

Ritz-Timme, S., C,Cattaneo., M,J.Collins., E,R.Waite., H,W.Schütz. dan H,J. Kaatsch., H, I. M. Borrman. 2000. Age Estimation: The State of The Art in Relation to The Specific Demands of Forensic Practise. International Journal of Legal Medicine $113: 129$ 136

Sahni, D., Indar, Jit., dan Sanjeev. 1994. Time of Fusion of Epiphyses at the Elbow and Wrist Joints in Girls of
Northwest India. Forensic Science International 74: 47-55

Saint-Martin, P., Camille,R., Fabrice,D., Hervé,R., Daniel,R. dan Norbert,T. 2014. Evaluation of An Automatic Method for Forensic Age Estimation by Magnetic Resonance Imaging of The Distal Tibial Epiphysis-A Preliminary Study Focusing on The 18-year Threshold. International Journal of Legal Medicine 128:675683

Schmeling, A., P.Manuel.G., J,Luis.P. dan M,Irene.L. 2011. Forensic Age Estimation in Unaccompanied Minors and Young Living Adults. InTech: Croatia. hal :77-120

Schmidt, S., Beate,K., Ronald,S., Walter,R. dan Andreas,S. 2007. Comparative Analysis of The Applicability of The Skeletal Age Determination Methods of Greulich-Pyle and ThiemannNitz for Forensic Age Estimation in Living Subjects. International Journal of Legal Medicine 121:293296

Schmidt, S., Inna,N., Ronald,S. dan Andreas,S. 2008. Applicability of The Skeletal Age Determination Method of Tanner and Whitehouse for Forensic Age Diagnostics. International Journal of Legal Medicine 122:309-314

Schmidt, S., Inna.Nitz., Ronald.Schulz., Michael.Tsokos., dan Andreas.Schmeling. 2009. The Digital Atlas of Skeletal Maturity by Gilsanz and Ratib: A Suitable Alternative for Age Estimation of Living Individuals in Criminal Proceedings?. International Journal of Legal Medicine 123:489-494

Schmidt, Sven., Andreas.Schmeling., Per.Zwiesigk., Heidi Pfeiffer., dan Ronald.Schulz. 2011. Sonographic Evaluation of Apophyseal Ossification of The Iliac Crest in Forensic Age Diagnostics in Living Individuals. International Journal of Legal Medicine 125:271-276

Serin,J., Camille.R., Julien,P., Fabrice,D., Norbert,T., Frédéric,S. dan Pauline,S. 2016. Contribution of Magnetic Resonance Imaging of The 
Wrist and Hand to Forensic Age Assessment. International Journal of Legal Medicine

Stimson, P.G. dan Curtis,A.M.1997. Forensic Dentistry. CRC Press: New York. hal.80-95

Tersigni-Tarrant, Maria,T.A. dan Natalie,R.S. 2013. Forensic Anthropology : An Introduction. CRC Press : Boca Raton. hal 40-68

Thali, M.J., Mark,D.V. dan B,G.Brogdon. 2011. Brogdon's Forensic Radiology. CRC Press: Boca Raton 1-106

Vierra, D.N. 2011. Forensic Medicine from Old Problems to New Challenges. InTech : Croatia

Vierra, D.N. 2011. Forensic Medicine from Old Problems to New Challenges. InTech : Croatia

Wittschieber, D., Andreas,S., Sven,S., Walter,H., Heidi,P. dan Volker,V. 2013. The Risser Sign for Forensic Age Estimation in Living Individuals: A Study of 643 Pelvic Radiographs. Forensic Science Medicine and Pathology 9:36-43

Wittschieber, D., Christian,O., Volker,V., Martin,K., $\quad$ Ronald,S., Juan,H., Thomas,B., Klaus.Püschel., Frank.Ramsthaler.,

Heidi.Pfeiffer.,Sven.Schmidt., dan Andreas.Schmeling. 2015. Projection Radiography of The Clavicle: Still Recommendable for Forensic Age Diagnostics in Living Individuals?. International Journal of Legal Medicine 129:187-193

Wittschieber, D., Volker,V., Maximilian,T., Jiri,D. dan Andreas,S. 2014. Magnetic Resonance Imaging of The Iliac Crest: Age Estimation in Under-20 Soccer Players. Forensic Science Medicine and Pathology 10:198-202

Wittschieber, Daniel., Christian.Ottow., Ronald.Schulz., Klaus.Püschel., Thomas.B., $\quad$ Frank,R., Heidi,P.,Volker,V., Sven,S. dan Andreas,S. 2016. Forensic Age Diagnostics Using Projection Radiography of The Clavicle: 